\title{
Maternal mortality related to postpartum hemorrhage: a case-control study at the Befelatanana maternity of Madagascar
}

\author{
Rakotozanany Besaina ${ }^{1}$, Randriamahavonjy Romuald ${ }^{1}$, Rabearizaka Laingo ${ }^{2 *}$, \\ Ratsiatosika Tanjona ${ }^{2}$, Randriambelomanana J. A. ${ }^{1}$
} ${ }^{1}$ Department of Obstetrics and Gynecology, ${ }^{2}$ Department of Public Health, Faculty of Medicine, Antananarivo,
Madagascar

Received: 31 July 2018

Revised: 30 August 2018

Accepted: 05 October 2018

\section{*Correspondence:}

Dr. Rabearizaka Laingo,

E-mail: laingomalala07@gmail.com

Copyright: () the author(s), publisher and licensee Medip Academy. This is an open-access article distributed under the terms of the Creative Commons Attribution Non-Commercial License, which permits unrestricted non-commercial use, distribution, and reproduction in any medium, provided the original work is properly cited.

\section{ABSTRACT}

Background: Postpartum hemorrhage (PPH) remains the main cause of maternal death throughout the world. present goal was to determine the associated factors to maternal death in postpartum hemorrhage.

Methods: This was a retrospective case-control study; carried out within Befelatanana maternity, in Antananarivo, from January $1^{\text {st }}, 2013$ to December $31^{\text {st }}, 2015$, on parturients who presented PPH. The cases were represented by the parturients who died despite well-managed care, and the control, by the living parturients.

Results: Authors recorded 181 cases of PPH from 20,888 deliveries, with a prevalence of $0.86 \%$; 47 of them died and 134 were alive; the mortality rate by $\mathrm{PPH}$ is $25.96 \%$. Factors associated with death were low education $(\mathrm{p}=0.00$ OR:3.2), non-working ( $\mathrm{p}=0.01$, OR:2.4), multiparity ( $\mathrm{p}: 2.2$ OR:0.01), absence of prenatal care (p:0.01 OR:2.2), cesarean section (p:0.00 OR:5.5); Intrauterine Fetal Death ( $\mathrm{p}=0.02, \mathrm{OR}: 2.2)$; uterine atony ( $\mathrm{p}=0.03, \mathrm{OR} 2.1)$; the state of shock ( $p=0.00$ OR:57.8), sanitary evacuation ( $p=0.01$ OR: 2.4), the need for blood transfusion $(p=0.00$ OR: 3, 7), use of catecholamines ( $\mathrm{p}=0.00$, OR:17.5); delayed management ( $\mathrm{p}=0.01, \mathrm{OR}: 2.2)$, hemostasis hysterectomy $(\mathrm{p}=0.00$ OR: 8.67).

Conclusions: The decrease of maternal mortality related to PPH requires better monitoring of pregnancy, delivery and postpartum. Speed care management, improvement of technical platform and establishment of a powerful health system are also needed. Thus, the global reduction of poverty is indispensable.

Keywords: Associated factors, Maternal mortality, Postpartum hemorrhage

\section{INTRODUCTION}

Postpartum haemorrhage (PPH) is one of the most feared complications by obstetricians and their patients. It is defined as haemorrhage greater than $500 \mathrm{ml}$ occurring within 24 hours after delivery regardless of the route of delivery. ${ }^{1,2}$ Despite marked progress in the management of early postpartum haemorrhage; this remains a major public health problem; particularly in developing countries, where it is responsible for a high mortality rate of up to $30 \%$ of maternal deaths. Every four minutes, a woman dies of PPH. ${ }^{2}$ According to the WHO, obstetric haemorrhages cause 127000 deaths each year and remain the leading cause of maternal mortality, and the majority of these deaths occur in the hours following childbirth and in most cases are due to PPH. ${ }^{3}$ In Madagascar, PPH is the leading cause of maternal mortality and responsible for $31.48 \%$ of deaths. ${ }^{4}$ Most PPH deaths occur within the first 24 hours after delivery, and despite the identification of risk factors, PPH are mostly unpredictable. Improving women's care during delivery to prevent and treat $\mathrm{PPH}$ is indisputable. 
This is to determine the factors associated with maternal mortality during PPH and to propose solutions to improve the situation; that this work was done at the Gynecological and Obstetrical Service of the University Hospital of Befelatanana Antananarivo Madagascar.

\section{METHODS}

This was a retrospective case-control study; carried out in Befelatanana Maternity, the reference hospital of Gynecology-Obstetrics (CHU-GOB) in Antananarivo, capital of Madagascar; from January 1, 2013 to December 31, 2015.

\section{Inclusion criteria}

- Authors included all medical records of parturients who had a delivery beyond 22 weeks of amenorrhea, and who presented PPH. Each record was retained when the diagnosis of HPP was made by the senior.

\section{Exclusion criteria}

- Uncompleted files were excluded from this study.

The cases consisted of parturients who died despite management care in the CHU-GOB; and the control were represented by living parturients. Authors compared one case to three controls; matching with age and parity. Authors studied the prevalence of PPH, the proportion of maternal mortality, the socio-obstetric characteristics, as well as the management. The data was collected on a preprinted form, then saved to an Excel ${ }^{\circledR}$ file and finally analyzed with EPI info 7® software. Categorical variables were summarized using frequencies and percentages followed by the Pearson's chi-square test, Fisher's exact test to assess associations between the categorical measures. All statistical tests were performed at a significance level of 0.05 .

\section{RESULTS}

\section{Epidemiological characteristics}

During the period of present study, authors counted 181 HPP cases out of 20,888 deliveries, thus, a prevalence of $0.86 \%$. Among these, 47 died despite treatment and 134 were alive; which reports a lethality by $\mathrm{PPH}$ of $25.96 \%$.

Table 1: Frequency of postpartum hemorrhage (PPH) and maternal death from 2013 to 2015.

\begin{tabular}{|l|l|l|l|l|} 
Period & $\begin{array}{l}\text { Number } \\
\text { of births } \\
n=20888\end{array}$ & $\begin{array}{l}\text { PPH } \\
n=181\end{array}$ & $\begin{array}{l}\text { Maternal } \\
\text { death } \\
n=171\end{array}$ & $\begin{array}{l}\text { Maternal } \\
\text { death due } \\
\text { to PPH } \\
n=47\end{array}$ \\
\hline 2013 & 7185 & 72 & 56 & 16 \\
\hline 2014 & 6818 & 50 & 53 & 13 \\
\hline 2015 & 6885 & 59 & 64 & 18 \\
\hline
\end{tabular}

The number of maternal deaths for the study period was 171 for 20,202 live births (LB); giving a maternal mortality rate of $846 / 100,000 \mathrm{LB}$. The 47 deaths by PPH were accounted for $27.48 \%$ of maternal deaths. The numbers of deliveries, PPHs, and maternal death were stable during three consecutive years (Table 1).

Table 2: Maternal characteristics and risk of maternal death.

\begin{tabular}{|l|l|l|l|l|}
\hline & $\begin{array}{l}\text { Case } \\
\text { n }(\%)\end{array}$ & $\begin{array}{l}\text { Control } \\
\text { n(\%) }\end{array}$ & $\begin{array}{l}\text { OR } \\
(\text { IC:95\%) }\end{array}$ & P \\
\hline $\begin{array}{l}\text { Low instruction } \\
\text { level (<7 years) }\end{array}$ & $\begin{array}{l}26 \\
(55.3)\end{array}$ & $\begin{array}{l}37 \\
(27.6)\end{array}$ & $\begin{array}{l}3.2 \\
(1.5-6.8)\end{array}$ & 0.00 \\
\hline Housewife & $\begin{array}{l}32 \\
(68)\end{array}$ & $\begin{array}{l}62 \\
(46.3)\end{array}$ & $\begin{array}{l}2.4 \\
(1.1-5.3)\end{array}$ & 0.01 \\
\hline Multiparity & $\begin{array}{l}29 \\
(61.7)\end{array}$ & $\begin{array}{l}56 \\
(41.8)\end{array}$ & $\begin{array}{l}2.2 \\
(1.0-4.7)\end{array}$ & 0.01 \\
\hline
\end{tabular}

Housewives were the most vulnerable to PPH (OR:2.4 $\mathrm{p}: 0.00)$. Multiparity was twice important as death (OR:2.2 p:0.01). Low education was also a pejorative factor in maternal mortality (OR:3.2 p:0.00) (Table 2).

\section{Obstetrical characteristics}

The risk of HPP death was twice important when prenatal care wasn't followed well (PNC) (OR:2.2 p=0.018). The $\mathrm{PPH}$ secondary to cesarean section were much more severe and were strongly associated with death (OR:5.5 $\mathrm{p}=0.00)$. The same was true for deliveries with intrauterine fetal death (IUFD) (OR:5.3 p=0.000). Moreover, uterine atony was the most strongly associated etiology with the occurrence of death (OR:2.1 p=0.032). The presence of an hemorrhagic shock at arrival or at the beginning of treatment negatively influenced the prognosis of these patients (OR:57.8 p=0.00) (Table 3).

Table 3: Risk of maternal death with postpartum hemorrhage.

\begin{tabular}{|l|l|l|l|l|}
\hline & $\begin{array}{l}\text { Case } \\
\mathrm{n}(\%)\end{array}$ & $\begin{array}{l}\text { control } \\
\mathrm{n}(\%)\end{array}$ & OR & P \\
\hline $\begin{array}{l}\text { Absence of } \\
\text { prenatal care }\end{array}$ & $\begin{array}{l}29 \\
(61.7)\end{array}$ & $\begin{array}{l}56 \\
(41.8)\end{array}$ & $\begin{array}{l}2.2 \\
(1-4.7)\end{array}$ & 0.018 \\
\hline Cesarean & 21 & 17 & 5.5 & 0.00 \\
$(44.6)$ & $(12.7)$ & $(2.4-12.9)$ & \\
\hline $\begin{array}{l}\text { Intrauterine } \\
\text { fetal death }\end{array}$ & $\begin{array}{l}(2 \\
(46.8)\end{array}$ & $\begin{array}{l}19 \\
(14.2)\end{array}$ & $\begin{array}{l}5.3 \\
(2.3-12.1)\end{array}$ & 0.00 \\
\hline Uterine atony & $\begin{array}{l}33 \\
(70.2)\end{array}$ & $\begin{array}{l}70 \\
(52.2)\end{array}$ & $\begin{array}{l}2.1 \\
(1-4.6)\end{array}$ & 0.03 \\
\hline $\begin{array}{l}\text { Hemodynamic } \\
\text { shock }\end{array}$ & $\begin{array}{l}42 \\
(89.4)\end{array}$ & $\begin{array}{l}17 \\
(12.7)\end{array}$ & $\begin{array}{l}57.8(18.4- \\
194.8)\end{array}$ & 0.00 \\
\hline
\end{tabular}

\section{Management support}

A delay in management care of more than 60 minutes exposed the patients to mortality (OR:2.2 p=0.01). This delay was mainly related to sanitary evacuation, which was also strongly associated with mortality (OR:2.4 
$\mathrm{p}=0.01$ ). The need for blood transfusion was associated with mortality with an odds ratio of 3.7 and significant $\mathrm{p}$. Hemostasis hysterectomy was strongly correlated with mortality (OR:8.6 p=0.00). Finally, the use of catecholamines in order to correct hemodynamic disorders was extremely denigratory with an OR17.5 (Table 4).

Table 4: Management of postpartum hemorrhage and the risk of maternal death.

\begin{tabular}{|c|c|c|c|c|}
\hline & $\begin{array}{l}\text { Case } \\
\text { n }(\%)\end{array}$ & $\begin{array}{l}\text { Control } \\
\text { n }(\%)\end{array}$ & $\begin{array}{l}\text { OR } \\
\text { (IC95\%) }\end{array}$ & $\mathbf{P}$ \\
\hline $\begin{array}{l}\text { External } \\
\text { transfer }\end{array}$ & $\begin{array}{l}35 \\
(74.5)\end{array}$ & $\begin{array}{l}73 \\
(54.5)\end{array}$ & $\begin{array}{l}2.4 \\
(1.1-5.4)\end{array}$ & 0.01 \\
\hline $\begin{array}{l}\text { Delay in } \\
\text { management } \\
\geq 60 \text { minutes }\end{array}$ & $\begin{array}{l}29 \\
(61.7)\end{array}$ & $\begin{array}{l}56 \\
(41.8)\end{array}$ & $\begin{array}{l}2.2 \\
(1-4.7)\end{array}$ & 0.01 \\
\hline $\begin{array}{l}\text { Blood } \\
\text { transfusion }\end{array}$ & $\begin{array}{l}37 \\
(78.7)\end{array}$ & $\begin{array}{l}67 \\
(50)\end{array}$ & $\begin{array}{l}3.7 \\
(1.6-8.6)\end{array}$ & 0.00 \\
\hline $\begin{array}{l}\text { Vasoactive } \\
\text { drugs }\end{array}$ & $\begin{array}{l}19 \\
(40.4)\end{array}$ & $\begin{array}{l}5 \\
(3.7)\end{array}$ & $\begin{array}{l}17.5 \\
(5.5-59)\end{array}$ & 0.00 \\
\hline Hysterectomy & $\begin{array}{l}29 \\
(61.7)\end{array}$ & $\begin{array}{l}21 \\
(15.7)\end{array}$ & $\begin{array}{l}8.6 \\
(3.8-19.7)\end{array}$ & 0.00 \\
\hline
\end{tabular}

\section{DISCUSSION}

\section{Frequency of PPH}

During the period of present study, the frequency of PPH was 0.86 per 100 deliveries (Table 1). Present result is similar to some African authors' like Pambou, in Brazzaville, who found a frequency of $0.19 \%$ and Téguété, in Bamako, who found a ratio of $2.3 \% .^{5,6}$ By contrast, it is further less than many European and Latin American studies' results such as Dupont, who reported an overall incidence of PPH of $6.4 \%$ and Venditilli, of $3.36 \%$ for vaginal deliveries route and 2.83 for cesarean section and finally Carroli, in Argentina for 6\%..$^{7-9}$ This difference may be explained, on the one hand, by an underestimation of the prevalence of PPH in African studies, on the other hand by differences in diagnostic criteria. Indeed, in present maternity, due to lack of bag of collection, the diagnosis of HPP is made only on the visual appreciation of the bleeding. Whereas for Western authors, other than the systematic use of collection bags, a biological criterion (loss of hemoglobin higher than $2 \mathrm{~g} / \mathrm{dL}$ ) has been added to the classical definition of PPHs in order identify more unnoticed cases. ${ }^{7}$

This attitude allowed them to provide more accurate estimate of the overall incidence of PPH. Moreover, this difference could also mean heterogeneity in present immediate postpartum supervision, which could not detect moderate or important bleeding. present result highlights the need to improve immediate postpartum supervision and to standardize the clinical estimation of blood loss in present facility, for example through systematic quantification using a collection bag. Pooling the purchase of these bags could be a perspective.

\section{Maternal mortality for HPP}

Postpartum hemorrhage is one of the most dreaded complications in obstetrics because it is the leading cause of maternal mortality, especially in developing countries. present study found 47 death by PPH among the 171 maternal death, a specific mortality for PPH of $27.48 \%$. This result matches to the Fenomanana et al, who found $31.48 \%$ of deaths. ${ }^{4}$ This result also joins that of Pambou, in Brazzaville, who found that from HPP is $39.5 \% .^{5}$ For Téguété, it is $16.6 \% .^{6}$

For countries with a high standard of living, such as France, according to the preliminary results of the National Survey on Maternal Mortality, hemorrhages are the leading cause of maternal death with $33 \%$ of direct obstetric deaths in 1999- 2001 and according to Dupont, it remains the leading cause of maternal mortality, responsible for $20 \%$ of deaths over the period studied (2004-2006). ${ }^{7,10}$ However, in these countries the frequency of death by hemorrhage has been greatly decreased. In France, the overall mortality rate due to hemorrhage was $4.7 \%$ in 2013; while Lefevre did not notice any maternal deaths related to PPH over a 3-year period, because of health service's development and quality, and the availability of emergency obstetric care. ${ }^{11,12}$

On the other side, in Madagascar, PPH mortality remains very frequent. During present study, authors counted 47 deaths out of 181 cases of hemorrhage, a lethality of 25.9\%. Significant maternal lethality by $\mathrm{PPH}$ was also noted by Pambou with $39.5 \%$ of deaths. ${ }^{5}$ These high rates of death from deliveries' hemorraghe in developing countries are rooted in families' poverty and the local material and technics' inadequacy. From these facts, the reducing of postpartum hemorrhages' lethality requires an emphasize od health coverage that will bring services closer to users.

\section{Maternal mortality factors by PPH}

\section{Socioeconomic status}

Our study has shown that the low socioeconomic level has a negative impact on health, increasing PPH-causeddeath. Housewives and women with low levels of education were more vulnerable for PPH with ORs of 2.4 and 3.2, respectively. This relationship has been shown many times in the literature. Sepou found that death was more common among poor patients, with a significant difference. ${ }^{13}$ And according to Bohoussou, $70.3 \%$ had no level of education. ${ }^{14}$

\section{Prenatal consultation care}

The absence of PNC correlated significantly with the occurrence of mortality in present study (OR:2.2). Detection of some groups of risked women during PNC is commonly accepted. According to Subtil, risk factors 
that can be identified before birth are mother's age, ethnic origin, marital status, social and educational level, absence of prenatal follow-up, multiple pregnancy, preeclampsia, uterine scar and/ or a history of personal and/ or obstetric risk, including HPP. ${ }^{15}$ Diallo found that the maternal mortality rate rose from 6.9 per 1,000 in the group of women with no PNC to 2.9 per 1,000 for those who had at least four prenatal visits. ${ }^{16}$ For Téguété, the highest risk of PPH was observed when the pregnancy was not followed $(\mathrm{OR}=3.9){ }^{6}$ It is therefore necessary to educate women about the PNC's importance. Iron supplementation too is indicated. The place of delivery should be discussed and planned according to the HPP risks identified during prenatal follow-up as early as the third trimester.

\section{Atony}

Uterine atony significantly increased the risk of mortality (OR:2.16). This finding is classic in the literature. ${ }^{7,17,18}$ To prevent the atony of uterus, WHO recommends the use of uterotonics for $\mathrm{PPH}$ prevention delivery; if intravenous oxytocin is not available, WHO recommends that $800 \mu \mathrm{g}$ of sublingual Misoprostol should be administered. ${ }^{19}$ In Madagascar, the practice of these recommendations still needs to be evaluated. Moreover, multiparity is significantly associated with PPH mortality (OR: 2.2). It is necessary to promote the use of family planning to reduce large multiparity and too close pregnancies, that is the main source of uterine atony.

\section{Cesarean}

Cesarean section was the delivery route associated to maternal HPP mortality in present study (OR:5.56). The literature notices an increase in the morbidity and mortality related to cesarean section compared to vaginal delivery route. Dupont and Téguété have reported an increase in the incidence of severe PPH after cesarean delivery. ${ }^{6,7}$ And Deneux-Tharaux found that the risk of maternal death of the postpartum is multiplied by 3.5 after cesarean section, compared to the vaginal delivery route. ${ }^{20}$ Cesarean section has long been known to be a risk factor for mortality and morbidity, particularly of the hemorrhagic type. In present study, indications for cesarean section are already risk factors for hemorrhage from delivery. The placental abruptio and placenta praevia dominated. Thus, the solution necessarily passes through a strengthening of prenatal care, in order to detect and to properly manage pathologies during pregnancy, including blood pressure and placental insertion's abnormality. Intrauterine fetal death was strongly associated with maternal HPP mortality, with $\mathrm{OR}=5.33$. They related to delayed dystocia work; failure of attempted vaginal delivery route often with uterotonic abuse (oxytocin, misoprostol) and sometimes to uterine scarring; they also related to retro placental hematoma, uterine rupture, and hemorrhagic placenta praevia. These pathologies are risk factors for uterine atony, uterine rupture, coagulation disorder, and sometimes lead to severe hemorrhages.

\section{Hemodynamic shock}

Patients who were in shock at the beginning of their treatment care or at the time of admission had a high risk of death with $\mathrm{OR}=57$. Use of catecholamine to correct this state of shock was also strongly associated with maternal death. For Téguété, nearly one third of cases of postpartum hemorrhage were complicated by shock. ${ }^{6}$ To Frimigacci, the existence of a state of shock was predictive of maternal death RR: $120 .{ }^{18}$ Ben Nasr and Deneux-Tharaux found a statistically significant association between the occurrence of death and the use of catecholamines. ${ }^{11,20}$ The severity of the shock generally reflects a significant loss of blood due to delayed management and to lack of knowledge of the diagnosis. Hemodynamic instability may justify the use of vasoactive drugs; but it should be only used as a rescue method in extreme situations. The reduction of maternal mortality requires an increase of deliveries in the health facility because home hemorrhage is often fatal. Early treatment care and better training of medical staff should be done.

\section{Sanitary evacuation}

Postpartum hemorrhage (PPH) can occur in public or private centers that do not have the full range of necessary therapeutic arsenal (intensive care unit, surgery, transfusion). As a result, the transfer of a patient from one center to another is a common situation. In present study, evacuation was a factor of poor maternal prognosis, with OR:2.4. In France, this transfer involves different structures such as the ESP (Emergency Service Providers) composed by physicians, nurses and some anesthesists, in collaboration with the hospital team (obstetricians and anesthetists-intensive care units). They also use means of transport (ambulance, helicopter) that permit non-delayed evacuation. This transfer meets requirements that reduce the risk of death. ${ }^{21}$ All intensive care (sedation, ventilation, catecholamines, transfusion) is continued during transport; a direct contact between the maternity of origin and the team of the multidisciplinary center that will receive the patient is established in order to transmit all the medical and obstetric information and to validate the transfer's reasons. As a result, the transfer of these patients is extremely fast and well framed. As a result, mortality directly related to the decision to transfer is low. ${ }^{21}$

Unfortunately, sanitary evacuation is frequently involved in maternal mortality in Africa. Fenomanana and al showed that sanitary evacuation significantly exposed to a state of shock at admission. ${ }^{4}$ To Sepou, the duration of evacuation was at least 2 hours for $28.9 \%$ of patients; and the death rate among evacuees was $6.9 \% .^{13}$ 
In present study, the parturients, came from 80 kilometers, were transported in bad conditions, using urban taxi or bush taxi as means; on roads often in bad condition. Thus, authors suggest as solution, the establishment of a health program whose main activity would be the sanitary evacuations' achievement.

\section{A need for transfusion}

Intensive Care Unit of severe forms of PPH relies on the supply of labile blood product (LBP) in large quantities. In present study, the need for blood transfusion was a risk factor for OR mortality=3.70. For Téguété, the need for blood transfusion was $42.6 \%$ of cases of postpartum hemorrhage. ${ }^{6}$

The result of present study highlights the relationship between the importance of blood spoliation, the need for transfusion, and the maternal prognosis for PPH. WHO recommends maintaining a hemoglobin level between 7 and $9 \mathrm{~g} / \mathrm{dl}$ during the active bleeding phase. ${ }^{19}$ The availability of blood products is essential to achieve this goal. The city of Antananarivo has only one blood bank and transfusion center which is serving major hospitals in the capital. Orders for blood products take a long time and needs are only partly fulfilled. ${ }^{22}$ The establishment of a transfusion service in the maternity ward is desirable.

\section{Delayed management support}

In present study, a delay beyond 60 minutes in management was significantly associated with the risk of mortality (OR:2.24). This result agrees with the Fenomanana et al. ${ }^{4}$ For Fourn, who studied preventable maternal mortality in Benin, the delay between hospital admission time and first aid was, on average, of 1.58 \pm 2.1 hours for referrals. ${ }^{23}$

In present study, this delay is due to sanitary evacuations, that are slow processes. PPHs occurring at the hospital are properly monitored and do not usually suffer from such a delay. It thus leads us to ask questions about the medical staff's ability of evaluation the risks, the possession of a minimum first aids' material (catheter, serum, uterotonic, antibiotic), the criteria for evacuation and about these women's ability to afford the transportation costs as soon as possible. Therefore, it is necessary to improve the caregiver's skill to recognize PPHs and to transfer them quickly; periodic evaluation of the level of medical staff's knowledge could also improve the situation. Finally, decentralization policy and primary health care are essential.

\section{Hemostasis hysterectomy}

Obstetrical hysterectomy is a familiar practice for Obstetricians Gynecologists. They, indeed, have to know the indications and the specificities of its realization because it remains treatment of last resort in case of surgical conservative approaches' failure. In present study, hysterectomy was significantly associated with maternal mortality by PPH (OR:8.67).

High mortality associated with these hysterectomies is therefore common in Africa. To Randriambelomanana and al, its frequency was $0.19 \%$. The indications were mainly uterine rupture $(69 \%)$ and hemorrhage of delivery (19\%). Maternal mortality was high at $7.6 \% .^{24}$ Pambou counted $14.58 \%$ hemostasis hysterectomy. ${ }^{5}$

Hemostasis hysterectomy has become exceptional in developed countries. That is due to the pelvic arterial afferent embolization's development associated to various conservative technics for the treatment of hemorrhage in delivery. ${ }^{25}$

In present study, high mortality rate related to hysterectomy is explained by the patients' condition (often in shock) at the admission and by present technical platforms which do not allow practicing other alternatives of rescue. In an advanced stage, this may be ineffective to save patients. In a less extreme context, non-mutilating surgical techniques such as surgical vascular ligations, uterine compression and haemostatic suturing techniques (B-Lynch and Cho techniques) would be interesting alternatives and seem to be more adequate to present context. Thus, these techniques deserve to be widely distributed to all obstetric practitioners because they are as effective as hysterectomy in case of delivery's hemorrhage. ${ }^{26}$

\section{CONCLUSION}

Present study reports high maternal mortality related to postpartum hemorrhage. It has highlighted the associated factors to maternal death. It has too incriminated poverty, medical under-equipment and the problem of health care organization in Madagascar. It is essential to improve each stage of the patient care. Emphasis should be placed on the prevention of postpartum hemorrhage by identifying risk factors during prenatal care and by establishing an early diagnosis during third stage of labour. A multidisciplinary approach is useful to decrease maternal mortality rate.

\section{Funding: No funding sources Conflict of interest: None declared \\ Ethical approval: The study was approved by the Institutional Ethics Committee}

\section{REFERENCES}

1. Dolleya P, Beuchera G, Dreyfusa M. Initial obstetric management for postpartum haemorrhage after vaginal delivery. J Gynecol Obstet Biol Reprod. 2014;43:998-1008.

2. Nayamaa M, Moulayea A, Djibrill B, Garbaa M, Idia NM. Boukerrouc. Haemostasis hysterectomies in under-equipped countries: a vital gesture. 
Prospective study in a maternity hospital in Niger. Gynecol Obstet Fertil. 2006;34:900-5.

3. Schuurmans N, MacKinnon C, Lane C, Etches D. Prevention and management of postpartum haemorrhage. J Soc Obstet Gynaecol Can. 2000;22:282-94.

4. Fenomanana MS, Riel AM, Rakotomena SD, Andrianjatovo JJ, Andrianampanalinarivo HR. Risk factors for postpartum haemorrhage mortality at the Befelatanana Maternity Hospital-CHU Antananarivo-Madagascar. RARMU. 2009;1:4-7.

5. Pambou O, Ekoundzola R, Yoca G, Uzan S. Serious hemorrhages of delivery to C.H.U. from Brazzaville. Méd Afr Noire. 1996;43(7):418-22.

6. Téguété I, Sissoko A, Djiré MY, Traoré Y, Kayentao $\mathrm{K}$, Théra $\mathrm{T}$, et al. Postpartum haemorrhage in Mali: frequencies, causes, risk factors and prognosis. $38^{\text {th }}$ national days. Part Four Gynecology-Obstetrics of the World. Paris. 2014.

7. Dupont C, Rudigoz RC, Cortet M, Touzet S, Colin $\mathrm{C}$, Rabilloud $\mathrm{M}$, et al. Incidence, etiologies and risk factors of postpartum haemorrhage: population study in 106 French maternity hospitals. J Gynecol Obstet Biol Reprod. 2014;43:244-53.

8. Vendittelli F, Barasinski C, Bruno P, Lém ery D. Incidence of immediate postpartum hemorrhages in French maternity units: a prospective observational study. BMC Preg Childbirth. 2016;16:242.

9. Guillermo C, Cristina C, Edgardo A, Gulmezoglu M. Epidemiology of postpartum haemorrhage: a systematic review. Best Pract Res Clinic Obstet Gynaecol. 2008;22:999-1012.

10. CNEMM. National Confidential Inquiry into Maternal Deaths France, 2007-2009. INSERM. 2013.

11. Ben Nasr L, Marzouk SB, Kehila M, Jabri H, Thamleoui S, Maghrebiet H. Serious hemorrhage of peripartum in an intensive care unit in a Tunisian university level 3 center: epidemiology and risk factors for maternal mortality. Pan Afr Med J. 2015;21:277.

12. Lefèvre $\mathrm{P}$, Brucato $\mathrm{B}$, Mayaud A, Morello R, Deneux-Tharaux C, Bouvier-Colle $\mathrm{MH}$, et al. Evaluation of the implementation of regional management of postpartum haemorrhage by an audit of severe cases: before-after study (2002-2005). J Gynecol Obstet Biol Reprod. 2009;38:209-19.

13. Sepou A, Goddot M, Ngbale R, Gaunefet CE, Modanga Z, Fandema E, et al. Evolution of frequency and problems related to medical evacuations to the gynecology-obstetric department of Bangui Community Hospital. Clinic Mother Child Health. 2009;6.

14. Traore B, Thera TA, Kokaina C, Beye SA, Mounkoro N, Teguete I, et al. Maternal mortality in gynecology and obstetrics at Segou Regional Hospital in Mali Retrospective study of 138 cases. Mali Medical. 2010;25:2.

15. Binet C, Gastineau B, Rakotoson L. Early Fecundity in Madagascar: What Impact on Maternal and Child Health?. IRD. 2005

16. Diallo FB, Diallo AB, Diallo Y, Goma O, Camara Y, Cisse M, et al. Maternal Mortality and Lifestyle Risk Factors. Méd Afr Noire. 1998;45.

17. Waltisperger D, Delaunay V. Evolution of the mortality of children and mothers in Madagascar: the deadline. 2015.

18. Frimigacci D, Morel O, Bricou A, Gayat É, Barranger E. Objective severity markers in women with severe postpartum. haemorrhage: a 310-case series. Gynecol Obstet Fertil. 2013;41(12):687-91.

19. OMS. WHO recommendations for the prevention and treatment of postpartum haemorrhage. WHO editions. 2014.

20. Deneux-Tharaux C, Carmona E, M-H Bouvier-Colle Marie, Bréartet G. Caesarean delivery and maternal postpartum mortality, France, 1996-2000. BEH thematic. 2006.

21. Rossignol M, Rozenbergb A. Modalities of an interhospital transfer in the context of a severe postpartum haemorrhage. J Gynecol Obstet Biol Reprod. 2000;29:501-8.

22. Andriamandranto HU, Rakotozanany B, Rajaonarison TJ, Fenomanana J, Fenomanana MS, Rakoto Alison AO, et al. Blood transfusion in obstetrical practice at the Befelatanana Gynecology and Obstetrics Hospital Center. JMGO. 2015;2:12-5.

23. Fourn L, Lokossou, Fayomi EB, Yacoubou M. Preventable maternal mortality in hospitals in a department in Benin. Méd Afr Noire. 2000;47.

24. Randriambelomanana JA, Botolahy ZA, Rakotoarivony ST, Herinirina SAE, H Rasataharifetra H, Ratsivalaka R. Obstetric hysterectomies performed at the maternity ward of Toamasina University Hospital Madagascar. RARMU. 2011;3:8-11.

25. Coatleven F, Vandenbossche F, Richez B, Horovitz J. Haemostasis hysterectomy. J Gynecol Obstet Biol Reprod. 2010;39:S1-S342.

Cite this article as: Rakotozanany $\mathrm{B}$,

Randriamahavonjy R, Rabearizaka L, Ratsiatosika T, Randriambelomanana JA. Maternal mortality related to postpartum hemorrhage: a case-control study at the Befelatanana maternity of Madagascar. Int J Reprod Contracept Obstet Gynecol 2019;8:121-6. 